\title{
Surfactants: their role in preventing the precipitation of proteins by tannins in insect guts
}

\author{
Michael M. Martin and Joan S. Martin \\ Division of Biological Sciences, University of Michigan, Ann Arbor, Michigan 48109, USA
}

\begin{abstract}
Summary. Much more tannic acid or pin oak tannin is required to precipitate the abundant leaf protein, ribulose1,5-bisphosphate carboxylase/oxygenase (RuBPC), from Manduca sexta gut fluid adjusted to $\mathrm{pH} 6.5$ than is required to precipitate this protein from an aqueous buffer at the same $\mathrm{pH}$. This finding demonstrates that some characteristic of $M$. sexta gut fluid, in addition to its basicity, counteracts the potential of tannins to precipitate ingested proteins. Gut fluid of $M$. sexta has a surface tension of 36-39 dynes/ $\mathrm{cm}$, indicating the presence of surfactants. Lysolecithin and linoleoylglycine, surfactants known to be present in insect gut fluids, also interfere with the precipitation of RuBPC by tannins at $\mathrm{pH} 6.5$. It is concluded that detergency is a widespread property of insect gut fluids that counteracts the potential of tannins to precipitate dietary proteins, and it is argued that there is no longer any justification for continuing to refer to tannins as digestibility-reducing-substances. Finding that there has been no formidable barrier to the evolution of mechanisms that counter a generalized antidigestive action by tannins is difficult to reconcile with the idea that reduced digestibility is an evolved anti-herbivore adaptation of apparent plants.
\end{abstract}

\section{Introduction}

Tannins are water-soluble phenolic componds that occur widely in vascular plants. They have adverse effects upon organisms as diverse as viruses, bacteria, fungi, insects, reptiles, birds and mammals (Swain 1979), and they have been accorded an important role as defensive chemicals that protect plant tissues from herbivore attack (Feeny 1976; Rhoades and Cates 1976). Since tannins are known to precipitate proteins (van Sumere et al. 1975; Hagerman and Butler 1981; McManus et al. 1983), it has been suggested that they might reduce the digestibility of plant tissue, either by precipitating the proteins of the foliage or the digestive enzymes of an herbivore (Feeny 1976; Rhoades and Cates 1976). Since ribulose-1,5-bisphosphate carboxylase/oxygenase (RuBPC) often makes up as much as $25 \%$ of the total protein and $25-50 \%$ of the soluble protein in photosynthetic tissues (Singer et al. 1952; Akazawa 1970; Lyttleton 1973; Jensen and Bahr 1977), it is a major dietary protein for any foliage-feeding insect. Its interactions with tannins

Offprint requests to: M.M. Martin are, therefore, particularly relevant to an evaluation of the potential role of tannins as digestibility-reducing substances. In an earlier study (Martin and Martin 1983), we showed that tannic acid, quebracho and pin oak (Quercus palustris) tannins precipitate many times their weight of RuBPC at $\mathrm{pH}$ values between 6.0 and 8.0 , but that these polyphenols precipitate little or none of this protein at $\mathrm{pH}$ values above 8.0 in the presence of $0.17 \mathrm{M}$ sodium chloride.

Since many tannin-protein complexes that are insoluble at neutral or slightly acidic $\mathrm{pH}$ values readily dissolve under more basic conditions (Hagerman and Butler 1978), it has been suggested that the high alkalinity of the gut fluids of many herbivorous lepidopteran larvae is a counter-adaptation to tannins (Feeny 1970; Berenbaum 1980). However, there are other mechanisms besides the maintenance of alkaline gut conditions by which herbivores avoid the potentially harmful effects of these compounds. Many polyphagous acridids, grasshoppers with neutral or slightly acidic gut fluids, are quite tolerant of tannins (Bernays and Chamberlain 1980; Bernays et al. 1980, 1981). The lack of any adverse effects of tannic acid on the locust, Schistocerca gregaria, has been attributed to the hydrolysis of tannic acid in the gut by $\beta$-glucosidases, adsorption of tannic acid on the peritrophic membrane, and "some other unknown factor" (Bernays 1981).

Insoluble tannin-protein complexes are readily solubilized by detergents (Goldstein and Swain 1965; Oh et al. 1980). While the surfactant properties of insect digestive fluids have received only limited study, the presence of surfactants has been established in the cabbageworm, Pieris brassicae (Turunen and Kastari 1979), the cricket, Gryllus bimaculatus (Collatz and Mommsen 1974), and the predatory beetle, Dytiscus marginalis (Vonk 1969).

In this study we have investigated the effects of detergents known to occur in insect gut fluids on the interaction of tannic acid and pin oak tannins with RuBPC at pH 6.5, a $\mathrm{pH}$ at which RuBPC ordinarily forms an insoluble complex with tannins. We have also explored the interaction of tannic acid and pin oak tannins with RuBPC in the gut fluid of the tobacco hornworm, Manduca sexta, and have discovered that even at a $\mathrm{pH}$ of 6.5 there is some factor present that interferes with precipitation. Finally, we have demonstrated the presence of surfactants in the gut fluid of this insect and propose that detergency, in addition to basicity, counteracts the potential of tannins to reduce the digestibility of ingested proteins. 


\section{Materials and methods}

\section{Preparation of extracts of pin oak foliage}

Pin oak leaf powder ( $40 \mathrm{mg}$ dry wt) was extracted twice for $8 \mathrm{~min}$ with $1.6 \mathrm{ml}$ of boiling $50 \%(\mathrm{v} / \mathrm{v})$ aqueous methanol (Martin and Martin 1983). The extract was concentrated to dryness at reduced pressure, and the residue redissolved in water. Material that did not dissolve was removed by centrifugation. This method of extraction produced an extract with 5 times the protein-precipitating capacity of the $70 \%$ aqueous acetone extract recommended by Foo and Porter (1980).

\section{Preparation of gut fluid}

Gut fluid ( $\mathrm{pH} 8.4-9.5$ ), collected from an incision in the anterior portion of the midgut was centrifuged $(32,000 \times \mathrm{g}$, $15 \mathrm{~min}, 4^{\circ} \mathrm{C}$ ) and deproteinized by mixing with 9 volumes of $95 \%$ ethanol. After $20 \mathrm{~min}$ at $5^{\circ} \mathrm{C}$, the mixture was centrifuged $\left(14,000 \times \mathrm{g}, 15 \mathrm{~min}, 4^{\circ} \mathrm{C}\right)$, solvent was removed from the supernatnat solution at reduced pressure, and the residue redissolved in a volume of water equal to $26.5 \%$ of the original. This concentration of gut fluid was used so that the final test solution (prepared by combining the RuBPC solution, gut fluid, buffer and tannin solution as described below) would have a concentration of gut fluid equivalent to the original.

\section{Synthesis of linoleoylglycine}

To $0.234 \mathrm{~g}$ of glycine in $1.5 \mathrm{ml}$ of $2 \mathrm{~N}$ potassium hydroxide, cooled to $0^{\circ} \mathrm{C}$, was added dropwise $0.5 \mathrm{~g}$ linoleoyl chloride and $1.0 \mathrm{ml}$ of $2 \mathrm{~N}$ potassium hydroxide. The mixture was stirred for 30 min with a magnetic stirring bar, after which $20 \mathrm{ml}$ of water was added. The mixture was acidified with concentrated hydrochloric acid and extracted with ether. The ether extract was washed with water until the extracts were neutral, dried over anhydrous sodium sulfate, and evaporated to dryness. The waxy residue was recrystallized from petroleum ether, giving $0.5 \mathrm{~g}$ of purified linoleoylglycine, m.p. $70-72^{\circ} \mathrm{C}$; lit value, $64-67^{\circ} \mathrm{C}$ (Tsuchiki et al. 1965).

\section{Precipitation of $R$ R BPC by tannins}

A stock solution of RuBPC and surfactant (or gut fluid) was prepared by combining $13 \mathrm{ml}$ of a solution of RuBPC $(2.5 \mathrm{mg} / \mathrm{ml})$ in buffer $(0.1 M \mathrm{MES}, 0.17 \mathrm{M} \mathrm{NaCl}, \mathrm{pH} 6.5)$ with $6.5 \mathrm{ml}$ of surfactant solution (or concentrated deproteinized gut fluid), adjusting the $\mathrm{pH}$ to 6.5 with $0.5 \mathrm{M} \mathrm{HCl}$, and adding buffer to a final volume of $22 \mathrm{ml}$. In the control, the surfactant (or gut fluid) was replaced by buffer. To a $1.35-\mathrm{ml}$ aliquot of this stock solution was added $0.15 \mathrm{ml}$ of water or of tannic acid or pin oak tannin solution. Following centrifugation $\left(32,000 \times \mathrm{g}, 15 \mathrm{~min}, 20^{\circ} \mathrm{C}\right)$, the pellet was gently rinsed with $1.0 \mathrm{ml}$ of buffer. The combined supernatant and rinse solution was applied to a $1.7 \times 5.0-\mathrm{cm}$ column of Sephadex G-25 (Pharmacia, PD-10) equilibrated in MES buffer. Proteins were eluted in $3.5 \mathrm{ml}$ of the same buffer. Protein in the eluent was assayed by mixing a $50 \mu 1$ aliquot with $2.5 \mathrm{ml}$ of Coomassie Brilliant Blue G-250 dye reagent (BioRad Protein Dye Reagent, 1:4 dilution), and determining $\mathrm{A}_{595}$ after 6 min (Bradford 1976) using a blank of $50 \mu \mathrm{l}$ of buffer plus $2.5 \mathrm{ml}$ of the dye reagent. The absorbance at 595 was converted into $\mathrm{mg}$ RuBPC in solution by the use of a calibration curve constructed on the same day as the assay. Surfactant (or gut fluid) was included in the protein solutions used for calibrating those experimental solutions containing surfactant (or gut fluid). From a determination of the amount of protein in the original solution and the amount remaining after the addition of tannic acid or pin oak tannins, the amount precipitated was calculated.

\section{Chemical sources}

Glycine (Sigma G-7126), linoleoyl chloride (Sigma L-5753), lysolecithin (Sigma L-5379), MES (Calbiochem-Behring 475893), RuBPC (Sigma R-8000), sodium oleate (Sigma 0-7501), tannic acid (Sigma T-0125).

\section{Surface tensions}

Surface tension was measured on as little as $25 \mu$ of sample using the horizontal thick-walled capillary apparatus of Ferguson (1943).

\section{Results}

\section{Surfactant properties of $M$. sexta gut fluid}

The surface tension of $M$. sexta gut fluid is 36-39 dynes/cm, and does not increase much above that value until the gut fluid has been diluted 10 -fold or more (Fig. 1). This indicates that not only are surfactants present, but that they are present at about 10 times the critical micelle concentration (CMC), which is the concentration at which there is a transition between the surfactant in the free, unassociated state and the micellar state. Surface tension measurements on the gut fluids of other insect species suggest that surfactants occur widely in insect digestive fluids (Table 1).

Only two surfactants from insect gut fluids have been characterized. Lysolecithin, generated during the digestion

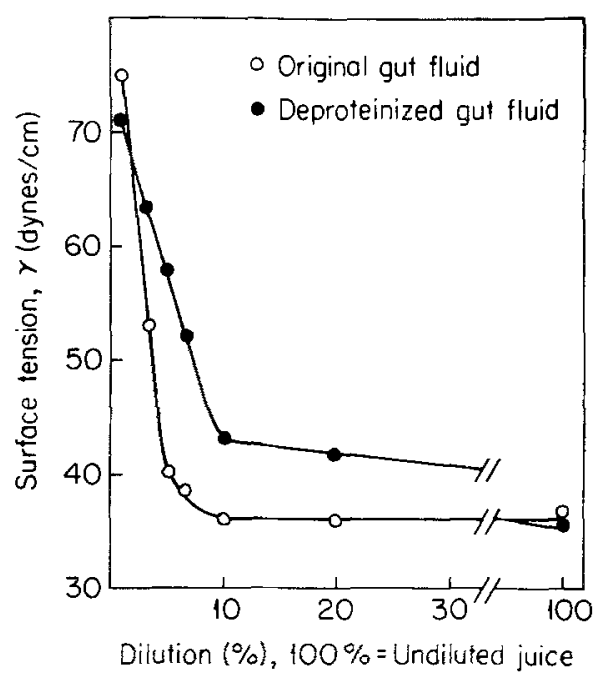

Fig. 1. Effect of dilution on surface tension $(\gamma)$ of $M$. sexta gut fluid. Gut fluid was obtained from fifth instar larvae weighing less than $5 \mathrm{~g}$, reared from eggs on an artificial agar-based diet (Yamamoto 1969) supplemented with wheat germ oil $(2.99 \mathrm{~g} /$ $1000 \mathrm{~g}$ diet) 
Table 1. Surface tensions of gut fluids from $G$. bimaculatus adults, fifth instar nymphs of $M$. sanguinipes, D. marginalis larvae, and late instar larvae of three lepidopteran species

\begin{tabular}{|c|c|c|}
\hline Species & $\gamma($ dynes $/ \mathrm{cm})$ & Source \\
\hline \multicolumn{3}{|l|}{ Orthoptera } \\
\hline Gryllus bimaculatus & $37-42$ & $\begin{array}{l}\text { Collatz and } \\
\text { Mommsen } \\
\text { (1974) }\end{array}$ \\
\hline Melanoplus sanguinipes & 33 & This study \\
\hline \multicolumn{3}{|l|}{ Coleoptera } \\
\hline \multicolumn{3}{|l|}{ Lepidoptera } \\
\hline Anisota senatoria & 34 & This study \\
\hline Hyalophora cecropia & 42 & This study \\
\hline Manduca sexta & $36-39$ & This study \\
\hline
\end{tabular}

of phospholipids, is present in $P$. brassicae (Turunen and Kastari 1979), and long chain fatty acyl conjugates of amino acids are present in G. bimaculatus (Collatz and Mommsen 1974).

\section{Precipitation of RuBPC from $M$. sexta gut fluid and surfac-} tant solutions by tannins

When RuBPC is dissolved in $M$. sexta gut fluid adjusted to a $\mathrm{pH}$ of 6.5 , much larger amounts of tannic acid or pin oak tannins are required to bring about precipitation of an insoluble complex than when this protein is dissolved in an aqueous buffer at the same $\mathrm{pH}$ (Table 2). While $300 \mu \mathrm{g}$ of tannic acid precipitates all $2.0 \mathrm{mg}$ of RuBPC from $1.5 \mathrm{ml}$ of a buffer solution at $\mathrm{pH} 6.5$, this amount of tannic acid precipitates only $0.3 \mathrm{mg}$ of this protein when it is dissolved in $1.5 \mathrm{ml}$ of $M$. sexta glut fluid, adjusted to a $\mathrm{pH}$ of 6.5 . Even $500 \mu \mathrm{g}$ of tannic acid fails to precipitate the entire $2.0 \mathrm{mg}$ of RuBPC dissolved in the gut fluid. Likewise, a given amount of pin oak tannins precipitates much less RuBPC from $M$. sexta gut fluid adjusted to $\mathrm{pH} 6.5$ than from a buffer at the same $\mathrm{pH}$. These experiments clearly demonstrate that some characteristic of $M$. sexta gut fluid, in addition to its alkalinity, interferes with the formation and precipitation of insoluble complexes between RuBPC and tannins.

The precipitation of RuBPC-tannin complexes from dilute solutions of surfactants known to occur in insect gut fluids also requires larger quantities of tannin than are required to precipitate such complexes from aqueous solutions lacking surfactants (Table 2). Lysolecithin and linoleoylglycine at concentrations 10 and 7 times their CMC's, respectively, concentrations that are comparable to that of the surfactant in $M$. sexta gut fluid, are as effective as gut fluid at preventing the precipitation of RuBPC by tannic acid and pin oak tannins. These results strongly suggest that surfactants are responsible for interfering with the formation of insoluble RuBPC-tannin complexes in $M$. sexta gut fluid when the $\mathrm{pH}$ has been reduced to 6.5.

Sodium oleate, another surface active substance that would be generated during the digestion of lipids, is ineffective in preventing precipitation of RuBPC by tannic acid and much less effective than gut fluid or the two detergents in preventing precipitation by pin oak tannins.

\section{Discussion}

Since the diet of $M$. sexta does not include tannin-rich plants, and since the gut fluid of this species ordinarily has a pH between 8.4 and 9.5 , it can hardly be argued that the presence of surfactants that interfere with the formation of insoluble RuBPC-tannin complexes at $\mathrm{pH} 6.5$ is an evolved adaptation to cope with ingested tannins. The significance of this study lies rather in its demonstration that the detergency of insect gut fluid can serve to counteract the potential protein-precipitating capacity of tannins. Since every study that has tested for surfactants in insect gut fluids has confirmed their presence, there is reason to believe that detergency is a common and widespread characteristic of insect digestive juices. In species with neutral or slightly acidic guts, such as $M$. sanguinipes (Table 1) and other acridids, gut fluid detergency could play a major role in interfering with the precipitation of ingested plant protein

Table 2. Effects of deproteinized gut fluid and various surfactants on the precipitation of RuBPC from aqueous media (pH 6.5) by tannic acid and pin oak tannins. The assay mixture contained $2 \mathrm{mg}$ RuBPC. Values are $\overline{\mathrm{x}} \pm \mathrm{SEM}$ for the number of replicates given in brackets. CMC is the critical micelle concentration; MES is 2-(N-morpholino)ethanesulfonic acid

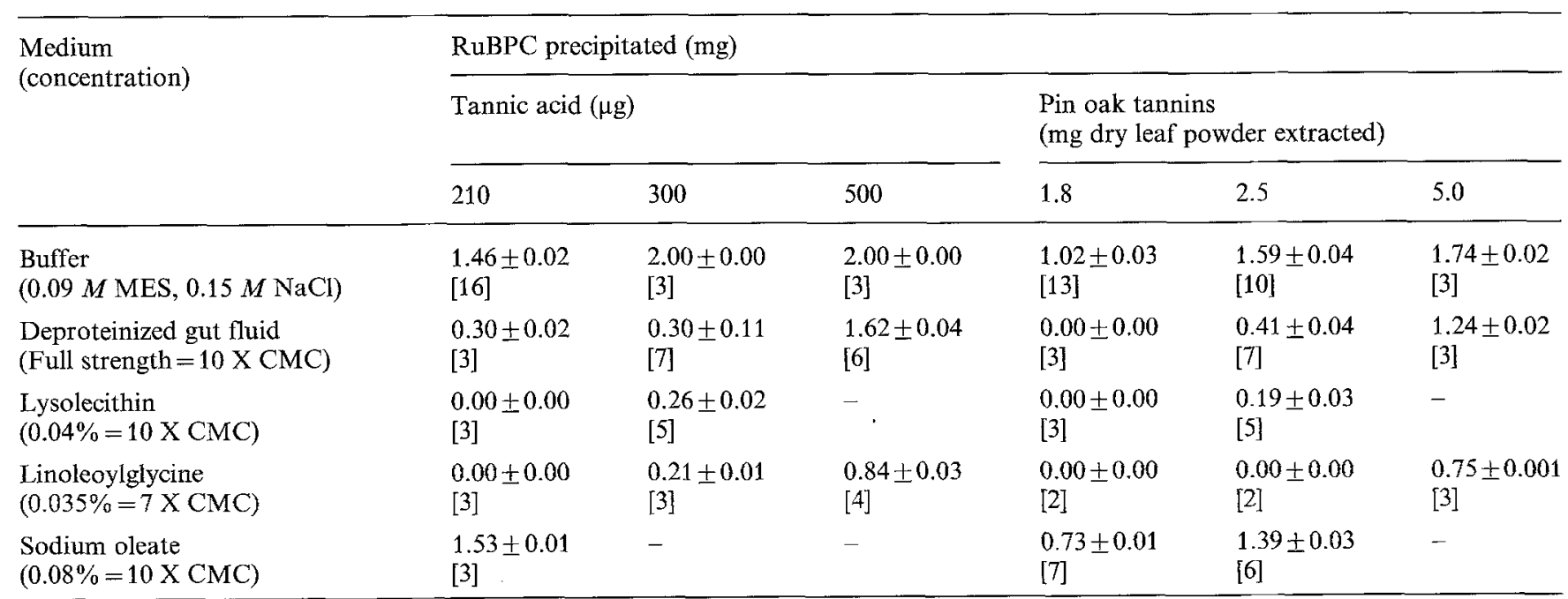


by tannins. Perhaps surfactants in the gut fluid are the "other unknown factor" hypothesized by Bernays (1981).

The hypothesis that tannins owe their effectiveness as defensive chemicals to generalized, dose-dependent antidigestive properties includes an assumption that counter-adaptations to such a mode of action are difficult to evolve. Finding that a widespread, possibly even ubiquitous, trait of the digestive systems of herbivores can interfere with the potential of tannins to precipitate a major dietary protein is a challenge to that assumption. Indeed, it is becoming increasingly evident that the digestive systems of insects possess a number of characteristics that could counteract the potential antidigestive properties of tannins. Not only does the detergency and/or alkalinity of gut fluid interfere with the formation of insoluble tannin-protein complexes, but in addition some species possess digestive $\beta$-glucosidases that are able to degrade hydrolyzable tannins, and peritrophic membranes that can adsorb tannins and remove them from the gut mileu (Bernays 1981). Whether any of these traits has evolved specifically in response to diets high in tannins is not at all clear, since they occur widely in species with low-tannin or tannin-free diets as well as species with high-tannin diets. However, what is clear is that the evolution of mechanisms that effectively counter a generalized antidigestive action by tannins is not such an unlikely event, whatever the selection pressures may have been that resulted in their evolution.

It is noteworthy that in those cases in which tannins have been shown to have an adverse effect upon the growth and survival of insect herbivores and in which the mode of action has been determined, it has been found that they act by inhibiting feeding or causing cell damage, not by interfering with digestion and assimilation (Bernays et al. 1980; Bernays 1981; Klocke and Chan 1982; Reese et al. 1982). Indeed, we are not aware of a single case in which ingested tannins have been demonstrated to reduce the efficiency of protein digestion in an insect herbivore. In our opinion, it is neither justifiable nor useful to continue to refer to tannins as digestibility-reducing-substances. A moratorium on the use of this unwarranted designation, at least until the appearance of an unambiguous demonstration of this mode of action, would allow discussions of the role of tannins in plant-insect interactions to focus upon the well-documented properties of these substances as feeding deterrents and toxins.

Acknowledgements. This research was supported by a grant from the National Science Foundation (DEB 80-22634). We thank Barbara Joos for $M$. sexta larvae, and David Shappirio, Dan Lawson and Keith Landa for other insect species. We thank Drs. Peter Becker and Beverly Rathcke for their comments and criticisms.

\section{References}

Akazawa T (1970) The structure and function of fraction-I protein. Progr Phytochem 2:107-141

Berenbaum M (1980) Adaptive significance of midgut $\mathrm{pH}$ in larval Lepidoptera. Am Nat 115:138-146

Bernays EA (1981) Plant tannins and insect herbivores: an appraisal. Ecol Entomol 6:353-360

Bernays EA, Chamberlain DJ (1980) A study of tolerance of ingested tannin in Schistocerca gregaria. J Insect Physiol $26: 415-420$

Bernays EA, Chamberlain DJ, McCarthy P (1980) The differential effects of ingested tannic acid on different species of Acridoidea. Entomol Exp Appl 28:158-166
Bernays EA, Chamberlain DJ, Leather EM (1981) Tolerance of acridids to ingested condensed tannins. $\mathbf{J}$ Chem Ecol 7:247-256

Bradford M (1976) A rapid and sensitive method for the quantitation of microgram quantities of protein utilizing the principle of protein-dye binding. Anal Biochem 72:248-254

Collatz KG, Mommsen T (1974) Die Struktur der emulgierenden Substanzen verschiedener Invertebraten. J Comp Physiol 94:339-352

Feeny PP (1970) Seasonal changes in oak leaf tannins and nutrients as a cause of spring feeding by winter moth caterpillars. Ecology $51: 565-581$

Feeny P (1976) Plant apparency and chemical defense. Rec Adv Phytochem 10:1-40

Ferguson A (1943) Surface tension and its measurement. Endeavor $2: 3438$

Foo LY, Porter LJ (1980) The phytochemistry of proanthocyanidin polymers. Phytochemistry 19:1747-1754

Goldstein JL, Swain T (1965) The inhibition of enzymes by tannins. Phytochemistry 4:185-192

Hagerman AE, Butler LG (1978) Protein precipitation method for the quantitative determination of tannins. I Agric Food Chem 26:809-812

Hagerman AE, Butler LG (1981) The specificity of proanthocyanidin-protein interactions. J Biol Chem 256:4494-4497

Jensen RG, Bahr JT (1977) Ribulose-1,5-bisphosphate carboxylase-oxygenase. Ann Rev Plant Physiol 28:379-400

Klocke JA, Chan BG (1982) Effects of cotton-condensed tannin on feeding and digestion in the cotton pest, Heliothis zea. $\mathrm{J}$ Insect Physiol 28:911-915

Lyttleton JW (1973) Proteins and nucleic acids. Chem Biochem Herb 1:63-103

Martin JS, Martin M M (1983) Tannin assays in ecological studies. Precipitation of ribulose-1,5-bisphosphate carboxylase/oxygenase by tannic acid, quebracho, and oak foliage extracts. J Chem. Ecol 9:285-294

McManus J, Lilley TH, Haslam E (1983) Plant polyphenols and their association with proteins. In: Hedin PA (ed) Plant resistance to insects. ACS Symposium Series 208. American Chemical Society, Washington, D.C., pp 123-137

Oh HI, Hoff JE, Armstrong GS, Haff LA (1980) Hydrophobic interaction in tannin-protein complexes. J Agric Food Chem 28:394-398

Reese JC, Chan BG, Waiss Jr AC (1982) Effects of cotton condensed tannin, maysin (corn) and pinitol (soybeans) on Heliothis zea growth and development. J Chem Ecol 8:1429-1436

Rhoades DF, Cates RG (1976) A general theory of plant antiherbivore chemistry. Rec Adv Phytochem 10:168-213

Singer EJ, Eggman L, Campbell JM, Wildman SG (1952) The proteins of green leaves. IV. A high molecular weight protein comprising a large part of the cytoplasmic protein. J Biol Chem 197:233-239

Swain T (1979) Tannins and lignins. In: Rosenthal GA, Janzen DH (eds) Herbivores: their interaction with secondary plant metabolites. Academic Press, New York, pp 657-682

Tsuchiki Y, Suzuki Y, Kobayashi A, Saito C (1965) Acylated amino acids. Japanese Patent 10,571. Chemical Abstracts 63:5740b (1965)

Turunen S, Kastari T (1979) Digestion and absorption of lecithin in larvae of the cabbage butterfly, Pieris brassicae. Comp Biochem Physiol 62A:933-937

Van Sumere CF, Albrecht J, Dedonder A, de Pooter H, Pe I (1975) Plant protein and phenolics. In: Harborne JB, Van Sumere CF (eds) The chemistry and biochemistry of plant proteins. Academic Press, New York, pp 211-264

Vonk HJ (1969) The properties of some emulsifiers in the digestive fluids of invertebrates. Comp Biochem Physiol 29:361-371

Yamamoto RT (1969) Mass rearing of the tobacco hornworm. II. Larval rearing and preparation. $J$ Econ Entomol $62: 1427-1431$

Received September 8, 1983 